\title{
MONOPÓLIO MASCULINO DO XAMANISMO AMAZÔNICO: O CONTRA-EXEMPLO DAS MULHERES XAMÃ SHIPIBO-CONIBO*
}

Anne-Marie Colpron

A literatura dedicada aos povos das terras baixas sul-americanas defende geralmente a idéia de que o xamanismo é praticado essencialmente por homens, associando a função de "xamã"1 ao papel de caçador-guerreiro, paradigma da masculinidade. Apesar das evidências etnográficas da existência de mulheres xamãs em certas sociedades da Amazônia, os escritos que as mencionam tratam do assunto apenas de passagem (cf. Descola e Lory 1982; Chaumeil 2000; Overing 1986; Alès 1998; Murphy e Murphy 1974; Menget 1984): essas especialistas são usualmente vistas como casos excepcionais, não representativos e, no fim das contas, negligenciáveis. Foram descritas, principalmente, como xamãs de segunda ordem, com poderes menores (Métraux 1967) que não se desenvolvem senão em uma idade tardia - após a menopausa —, quando elas não são mais consideradas mulheres plenas em suas sociedades (Descola e Lory 1982; Bellier 1991; Roe 1988). Ora, em que medida esse papel secundário atribuído às mulheres xamãs pode ser generalizado ao conjunto da Amazônia? Esses dados traduzem, sempre, uma pesquisa etnográfica profunda sobre o problema, ou não resultariam antes, em certos casos, de uma perspectiva analítica própria aos pesquisadores ocidentais, ou mesmo de um simples desinteresse pelo tema das mulheres xamãs?

Esse questionamento é suscitado pelo caso shipibo-conibo, objeto deste artigo. Os textos a propósito do xamanismo nessa sociedade não diferem daqueles que tratam de outras regiões da Amazônia. As mulheres xamãs são pouco reconhecidas e freqüentemente omitidas, alguns autores tendo inclusive postulado que "apenas os homens podem ser curadores, atividades que exercem com a ajuda de alucinógenos" (Heise et alii 1999:71 — tradução minha). Todavia, o trabalho de campo etnográfico ${ }^{2}$ permitiu identificar uma dúzia de mulheres xamãs que, à imagem de seus homólogos masculinos, 
detêm poderes e funções variáveis. Contrariamente às suposições habituais sobre o xamanismo feminino, essas mulheres geralmente praticam sua arte desde uma idade fértil, conciliando seus papéis de mãe e xamã; exercem funções sociais que se acreditava comumente reservadas aos homens, e podem alcançar os estágios mais avançados do poder xamânico. Apresentando brevemente essas diferentes mulheres xamãs, este estudo busca matizar as categorias sexuais-tipo, próprias ao estudo do xamanismo amazônico.

\section{A dicotomia homem/mulher nos estudos antropológicos}

A existência de mulheres xamãs shipibo-conibo que detêm poderes comparáveis aos de seus confrades permite perguntar por que elas estão ausentes dos estudos etnológicos. Algumas categorizações científicas clássicas, que marcaram uma certa tradição intelectual parecem, em parte, responsáveis por tal negligência ${ }^{3}$. Os estudos que tratam de homens e mulheres se baseiam, o mais das vezes, sobre aquilo que, no sentido ocidental, funda sua diferença: a biologia. Uma vez que se distinguem por seus corpos, suas secreções e suas funções procriativas, o homem e a mulher são considerados como dois termos que devem, necessariamente, oporse. A partir de uma dessemelhança biológica, inferem-se relações sociais desiguais entre os sexos. Assim, a mulher, enquanto procriadora, é posta do lado da natureza, do doméstico e da submissão. Segue-se uma divisão "natural" do trabalho em que a mulher se vê excluída dos papéis sociais mais prestigiosos (Rosaldo 1974; Ortner 1974), como o xamanismo. Como justificar esse salto teórico, que passa de uma constatação biológica a uma constatação social? Um tal ponto de vista nega, a priori, as práticas sociais comuns aos dois sexos, e simplifica ao extremo as manifestações sociais de gênero, restringindo a mulher - enquanto categoria genérica - aos mesmos papéis sociais, independente das épocas e das sociedades.

A tradição teórica que reduz a mulher a seu papel reprodutivo, colocando-a como o contrário do homem, acarretou toda uma série de dicotomias nos estudos antropológicos: a mulher procriadora vs. o homem criador cultural (Ortner 1974); a mulher doadora de vida vs. o homem doador de morte (Atkinson e Rosaldo 1975); a mulher doméstica vs. o homem público (Rosaldo 1974); a mulher reprodutora vs. o homem produtor (Meillassoux 1975; Kirsch 1977); etc. Há um quarto de século, essas oposições simplistas vêm sendo desmanteladas por numerosos autores americanistas (Hugh-Jones 1979; Overing 1986; Gow 1989) que, entre outros, notaram o papel crucial das mulheres na produção da mandioca, e, a partir de então, ninguém 
mais pensaria em relegar as mulheres ao papel de reprodutoras. Esses importantes questionamentos não erradicaram, todavia, aqueles contrastes que continuam implicitamente presentes nas análises. Por exemplo, para contestar a oposição homem produtor vs. mulher reprodutora, diversos autores (Lorrain 2000; Jackson 1992; Bellier 1991) sublinharam o papel procriador do homem no plano simbólico: por meio da função de xamã, o homem se reserva o controle metafísico sobre a reprodução ${ }^{4}$. A mulher, que já detém esse privilégio no plano físico, não poderia acumular esses papéis. Assim, segundo Bellier:

A relação que a mulher grávida entretém com a sociedade masculina, e particularmente com os xamãs, demonstra existir uma competição entre os poderes reprodutivos assumidos pelas duas categorias sociais exemplares, definidas pela condição sexual. As mulheres são socialmente valorizadas ao tornarem-se mães, os homens, ao tornarem-se xamãs. Os dois movimentos conferem poder àqueles que os atestam: as mulheres são as mães reais do grupo, os xamãs, seus genitores putativos. As primeiras o são naturalmente, desde os tempos míticos, quando seus corpos foram transformados para isso; os segundos tornam-se tais por uma prática estrita, em que o controle mesmo de seus corpos libera o espírito no caminho do conhecimento [...] os papéis sociais devem ser claramente expostos e diferenciados [...] se as mulheres ou os xamãs abusassem deles e se esterilizassem mutuamente, a sociedade morreria em decorrência da transgressão (Bellier 1991:236-237).

Inadvertidamente, este argumento cede diante de uma nova oposição: a mulher procriadora biológica vs. o homem procriador no plano social e cósmico. Mais uma vez, remete-se ao papel biológico da mulher, reintroduzindo a dicotomia da qual se procurava escapar.

É forçoso constatar que todas essas oposições reconduzem-nos ao mesmo ponto de partida, beco sem saída teórico que parece necessário colocar em questão: a preeminência do biológico. Essa ótica é de tal modo enraizada em nossa herança científica ocidental, que se manteve no estudo do xamanismo: mesmo se o xamã é, o mais das vezes, descrito como transgressor de fronteiras (animal/humano, morte/vida etc), apenas o homem, que não é constrangido por sua biologia, pode ultrapassar suas barreiras corporais. O par mulher/homem é assim considerado através da dualidade natureza/cultura própria ao Ocidente. Entretanto, a divisão binária nature$\mathrm{za} /$ cultura não parece descrever adequadamente sociedades que não aderem a uma visão naturalista do mundo - crítica levantada, no caso das terras baixas sul-americanas, por P. Descola (1986; 1992; 1996). Segundo 
este autor, as ciências ocidentais vieram a conceber a natureza como uma crença universal, que possuiria em toda parte as propriedades e fronteiras que nossa própria cultura lhe atribui. A "natureza", tal como a definimos culturalmente, torna-se, então, a medida para definir outras sociedades, extrapolação que o autor considera etnocêntrica, uma vez que, na Amazônia, o ser humano é pensado em um vasto contínuo com os seres do ambiente, mantendo todos, laços de sociabilidade entre si. A natureza tornase, assim, o termo de uma relação social, daí o título de seu livro, La nature domestique (1986). Se, em certas sociedades, a dicotomia natureza/cultura não é adequada para descrever a relação entre seres humanos e espécies animais - idéia bem estabelecida na antropologia - por que ela o seria para explicar a relação entre homens e mulheres? Considerando que a associação da mulher à natureza e do homem à cultura provém de nossa própria tradição cultural, por que retomar essa categoria inoperante para fazer dela a principal divisão entre os sexos?

Tomar como estabelecido que essa divisão binária, utilizada em nossa própria cultura, fornece um ponto de partida analítico neutro e objetivo é, portanto, uma posição contestável (Yanagisako e Collier 1987). Nossos conceitos são forjados por uma história, por uma bagagem cultural: "cada polaridade tem sua própria história, mas também desenvolve significados relacionados a outras dicotomias" (Jordanova 1980:43). Cada termo implica uma relação complexa com um outro termo, o que torna essas oposições não-lineares e complexas, pois remetem a todo um sistema de pensamento influenciado por nosso passado. Assim, mesmo que já há algumas décadas, certas categorizações homens-mulheres, consideradas excessivamente redutoras, venham sendo contestadas, outras persistem ainda, notadamente a propósito do xamanismo: apenas o homem pode tornar-se xamã - aquele que, por seus poderes de curador e regenerador de energias, reproduz cosmicamente a sociedade; aquele que possui, também, a capacidade de aniquilá-la. Retorna então, implicitamente, a idéia de que apenas o homem, o caçador, o guerreiro, pode ser doador de morte; de que apenas o homem, enquanto o contrário da mulher, situa-se do lado da cultura, do público e da dominação. Essa perspectiva teórica explica, em parte, porque a questão da existência de mulheres xamãs não foi aprofundada entre os Shipibo-Conibo.

Parece ser então necessário pôr em dúvida a aplicabilidade das dicotomias tal como concebidas em nossa sociedade, e nos colocarmos em guarda contra a tendência a utilizar o discurso dominante do Ocidente, universalizando suas categorias e cegando-nos para outras maneiras de estruturar o mundo (Hviding 1996). As pesquisas sobre as terras baixas amazônicas consideram geralmente o par homem-mulher como elemento fundamental 
na estruturação socio-religiosa dessas populações, "matriz privilegiada na ordenação do ambiente social e simbólico" (Taylor 1979). O presente estudo não pretende contestar a importância da relação diferencial entre os homens e as mulheres. Ele critica, antes, a definição dicotômica dessa relação, pois uma tal (o)posição não permite abertura para a possibilidade de um xamanismo exercido pelas mulheres. Concordando com Hugh-Jones (2001), que se baseia nos estudos melanésios de Strathern (1988), pareceme necessário problematizar a questão do gênero na Amazônia: "ver a diferença de gênero simplesmente como um atributo fixo e naturalmente dado de homens e mulheres não faz justiça à riqueza e à complexidade estratificada das concepções indígenas" (Hugh-Jones 2001:253). O simbolismo de gênero remete a diversos níveis de sentido, que não são redutíveis a uma interpretação simples. Mais que dualistas, as classificações do universo, próprias à sociedade shipibo-conibo parecem ser de ordem circunstancial e referencial. Para compreender uma tal visão de mundo, comecemos por uma apresentação dessa sociedade.

\section{Sociedade e xamanismo shipibo-conibo: uma breve apresentação}

Hoje, cerca de 120 comunidades shipibo-conibo ocupam as margens do Ucayali e seus afluentes na floresta central do Peru, região de florestas tropicais denominada selva baja. O shipibo e o conibo se incluem entre as cerca de trinta línguas que compõem a família pano, e constituem no interior desta, segundo Erikson (1996), os falantes mais numerosos (23 mil sobre 40 mil Pano) e mais divergentes socialmente: como ribeirinhos, diferem dos Pano interfluviais por sua organização socioeconômica, com suas ricas várzeas permitindo-lhes uma horticultura mais intensiva, e a pesca ocupando um papel preponderante em sua alimentação. A denominação composta, shipibo-conibo, traduz a fusão de diversas populações que se casaram entre si, na seqüência de uma drástica baixa demográfica, resultado do choque epidemiológico provocado pela presença européia. Desde então, as terras shipibo-conibo são pontilhadas por outros grupos étnicos (Piro, Campa, Ashaninka, Cocama) e aldeias mestiças (caseríos), com os quais as relações são às vezes corteses, freqüentemente tensas. Em princípio (mas não de fato), todas as comunidades shipibo-conibo possuem uma escola primária bilíngüe, um posto de rádio e um posto sanitário, condições requeridas pelo governo nacional peruano para que obtenham o título de Comunidad Nativa ${ }^{5}$. Essas comunidades diferem umas das outras por seu modo de vida, por sua organização social e afiliação religiosa. Alguns casos 
extremos: Vencedor, situada no afluente Pisqui, conta com uma centena de membros de uma família extensa vivendo da caça, da pesca e horticultura; ao passo que São Francisco, localizada nas proximidades da segunda maior cidade da selva peruana, Pucallpa, cujas terras desmatadas e cursos d'água super-explorados motivam novos modos de subsistência - notadamente, atividades ligadas ao turismo, como o trabalho de guia, a produção de artesanato etc. - , conta com mais de dois mil habitantes, "não-parentes", e reúne igrejas distintas (católica, evangélica, adventista). Entre esses antípodas, desdobra-se todo um leque de possibilidades.

À imagem do retrato complexo dessa sociedade, o xamanismo shipiboconibo - por muito tempo considerado, a torto e a direito, como um fenômeno arcaico e imutável — é marcado por numerosas influências exógenas: elementos religiosos de diversas igrejas ocidentais; conhecimentos imputados aos vizinhos indígenas e mesmo aos especialistas mestiços das cidades e dos Andes. A despeito desse amálgama de saberes, a maior parte dos Shipibo-Conibo qualifica suas práticas xamânicas como "tradicionais", a elas se referindo como marcadores de sua identidade étnica desde os anos 1970, um movimento de revalorização da indianidade acompanha-se de uma revitalização do fenômeno xamânico (Chaumeil 1993), o que explica o número elevado de xamãs (uma centena, segundo Morin 1998) ${ }^{6}$. Ora, como sublinham vários Shipibo-Conibo, poucos deles "possuem um grande saber" (Arévalo 1986). Além disso, o termo shipibo-conibo que significa xamã, onánya, engloba diversas especialidades, cujo denominador comum é o ritual de consumo da ayahuasca ${ }^{7}$. Aqueles que habitam comunidades que ainda vivem da caça e da pesca exercem um papel de mediação junto aos mestres da caça; outros conduzem principalmente rituais de cura, ou se concentram mais (ou adicionalmente) no domínio amoroso (atividade solicitada sobretudo pelos mestiços, e que proporciona uma renda não desprezível). Trabalhar para mestiços e estrangeiros confere, às vezes, uma certa notoriedade aos onánya. No entanto, trabalhar exclusivamente para "outros" é algo malvisto, e o xamã é então considerado avaro (yôaxi ${ }^{8}$ ), por usar seus conhecimentos exclusivamente em benefício próprio.

Os Shipibo-Conibo nomeiam três tipos de especialistas xamânicos onánya, meráya e yobé, títulos que não são utilizados auto-referencialmente, mas antes atribuídos por seus pares (o sufixo bo é usado como pluralizador). No estágio mais avançado de sua carreira, o onánya se torna meráya, grau que se adquire e preserva por meio de um modo de vida rigoroso e ascético, o que explica o número restrito de meráyabo (segundo Arévalo (1986), menos de uma dezena de indivíduos) ${ }^{9}$. Yobé se traduz 
usualmente em espanhol por feiticeiro (brujo); entretanto, Arévalo (1986) e Tournon (1991a) o definem como xamã especialista na extração de projéteis patogênicos (yotó). Ainda que a maior parte dos xamãs possua este conhecimento, o termo yobé é considerado ofensivo, estando implicitamente associado ao mal (jakónma) ${ }^{10}$ : um parente próximo é qualificado de onánya e um estrangeiro de yobé, títulos circunstanciais, que parecem estar associados às relações de vizinhança ou parentesco com o xamã. O modo de agressão do yobé evoca as antigas funções dos caçadores-guerreiros, outrora valorizadas. Cada vez mais, porém, os Shipibo-Conibo se afastam do ideal do guerreiro, proclamando-se antes "índios civilizados e cristãos". Exercem um xamanismo que faz referência à Bíblia e aos santos, mas, paradoxalmente, combates sangrentos não estão ausentes de seus discursos. A terminologia repertoriada que faz referência aos tipos de especialistas não inclui um título diferente para as mulheres, o que poderia levar a crer que essas práticas sejam exclusivamente masculinas. Ora, a maior parte dos termos que designam os herboristas (raómis) ou os hueseros (tóbia$k a i)^{11}$, competências comumente encontradas nos dois sexos, são neutros. Por que os termos onánya, meráya e yobé deveriam ser diferentes? A necessidade de opor os papéis masculinos e femininos e categorizar por meio de um termo diferente os especialistas de cada sexo parece, nesse caso, uma preocupação inferida pelos pesquisadores ocidentais (Heise et alii 1999).

\section{As mulheres onányabo}

Ainda que as mulheres onányabo sejam menos numerosas do que seus confrades (cerca de uma mulher para cada dez homens) ${ }^{12}$, suas aquisições xamânicas revelam-se igualmente diversificadas: elas não atingem, todas, um estado equivalente de poder e não se dedicam às mesmas tarefas. Essa variabilidade deve nos advertir contra generalizações abusivas: extrapolar para o conjunto das mulheres, práticas exercidas por uma ou duas dentre elas, fornece um retrato insuficiente, de onde a importância de apresentar os diversos casos de onányabo femininos encontrados entre os ShipiboConibo (cf. Tabela 1). Essas onányabo (cf. Mapa 1) foram localizadas graças a uma viagem de reconhecimento efetuada de maio a outubro de 2000, em um percurso guiado por boatos sobre o assunto. As duas primeiras especialistas encontradas, Maria e Juana ${ }^{13}$, eram pouco versadas na arte xamânica, uma sendo muito idosa e a outra encontrando-se nos primeiros estágios de sua iniciação. Pareciam, assim, confirmar as suposições teóricas sobre a pouca importância das mulheres xamãs, ao passo que sua idade 


\section{Tabela 1}

\begin{tabular}{|c|c|c|c|c|c|c|}
\hline Nome & Idade & $\begin{array}{l}\text { Local de } \\
\text { nascimento }\end{array}$ & $\begin{array}{l}\text { Local de } \\
\text { residência }\end{array}$ & Estatuto & Atividade & $\begin{array}{l}\text { Idade de } \\
\text { iniciação }\end{array}$ \\
\hline $\begin{array}{l}\text { Maria } \\
\text { InínRabi }\end{array}$ & 65 & $\begin{array}{c}\text { Santa-Maria } \\
\text { Médio Ucayali }\end{array}$ & $\begin{array}{c}\text { Paoyan } \\
\text { Médio Ucayali }\end{array}$ & separada & $\begin{array}{c}\text { reduzida } \\
\text { casos benignos }\end{array}$ & 14 \\
\hline $\begin{array}{c}\text { Juana } \\
\text { Rara Bensho }\end{array}$ & 55 & $\begin{array}{c}\text { Santa-Ana } \\
\text { Médio Ucayali }\end{array}$ & $\begin{array}{c}\text { Santa-Ana } \\
\text { Médio Ucayali }\end{array}$ & casada & fase inicial & 50 \\
\hline $\begin{array}{c}\text { Emilia } \\
\text { Reshín Kate }\end{array}$ & 38 & $\begin{array}{l}\text { Conshanmay } \\
\text { Médio Ucayali }\end{array}$ & $\begin{array}{l}\text { Conshanmay } \\
\text { Médio Ucayali }\end{array}$ & casada & intensa & 18 \\
\hline $\begin{array}{c}\text { Justina } \\
\text { Kesén Rona }\end{array}$ & 42 & $\begin{array}{l}\text { Vencedor } \\
\text { Pisqui }\end{array}$ & $\begin{array}{l}\text { Vencedor } \\
\text { Pisqui }\end{array}$ & casada & intensa & 20 \\
\hline $\begin{array}{c}\text { Herminia } \\
\text { Níwen Kena }\end{array}$ & 69 & $\begin{array}{c}\text { Cruzmuñona } \\
\text { Baixo Ucayali }\end{array}$ & $\begin{array}{c}\text { Perto de Canaan } \\
\text { Médio Ucayali }\end{array}$ & casada & $\begin{array}{c}\text { reduzida } \\
\text { casos benignos }\end{array}$ & 18 \\
\hline Isabel & 40 & $\begin{array}{c}\text { Caco } \\
\text { Alto Ucayali }\end{array}$ & $\begin{array}{l}\text { San Salvador } \\
\text { Médio Ucayali }\end{array}$ & casada & com caboclos & 25 \\
\hline Angela & 65 & $\begin{array}{c}\text { Paoyan } \\
\text { Médio Ucayali }\end{array}$ & $\begin{array}{l}\text { Cidade de Yarina } \\
\text { Médio Ucayali }\end{array}$ & viúva & $\begin{array}{c}\text { casos benignos } \\
\text { ou com filhos }\end{array}$ & vintena \\
\hline $\begin{array}{c}\text { Aurora } \\
\text { Shanén Kena }\end{array}$ & 65 & $\begin{array}{l}\text { Dos de Mayo } \\
\text { Baixo Ucayali }\end{array}$ & $\begin{array}{c}\text { Colonia del Caco } \\
\text { Alto Ucayali }\end{array}$ & viúva & $\begin{array}{c}\text { não ingere mais } \\
\text { a ayahuasca }\end{array}$ & vintena \\
\hline $\begin{array}{c}\text { Rosa } \\
\text { Ronín Abe }\end{array}$ & 48 & $\begin{array}{c}\text { Shambo } \\
\text { Médio Ucayali }\end{array}$ & $\begin{array}{l}\text { Cidade de Yarina } \\
\text { Médio Ucayali }\end{array}$ & casada & intensa & 18 \\
\hline $\begin{array}{c}\text { Elisa } \\
\text { Reshín Wisna }\end{array}$ & 38 & Médio Ucayali & $\begin{array}{l}\text { San Francisco } \\
\text { Médio Ucayali }\end{array}$ & casada & aprendiz & 38 \\
\hline Manuela & 43 & $\begin{array}{c}\text { Painaco } \\
\text { Baixo Ucayali }\end{array}$ & $\begin{array}{c}\text { Paoyan } \\
\text { Médio Ucayali }\end{array}$ & casada & aprendiz & $\begin{array}{l}19 \text { (fracas- } \\
\text { sada), } 40\end{array}$ \\
\hline
\end{tabular}

OBS: Dados coletados em 2000/2001 


\begin{tabular}{|c|c|c|c|c|c|}
\hline $\begin{array}{l}\text { Mestre } \\
\text { onánya }\end{array}$ & $\begin{array}{l}\text { Parente } \\
\text { onánya }\end{array}$ & $\begin{array}{l}\text { Parceiros } \\
\text { rituais }\end{array}$ & Influência & $\mathrm{N}^{\circ}$ maridos & $N^{\circ}$ filhos \\
\hline $\begin{array}{c}\text { pai } \\
\text { marido }\end{array}$ & $\begin{array}{c}\text { pai } \\
\text { avô paterno }\end{array}$ & $\begin{array}{l}\text { sozinha } \\
\text { cunhado }\end{array}$ & evangelista & $\begin{array}{c}1 \text { (-) } \\
\text { (onánya) }\end{array}$ & $\begin{array}{c}4 \\
\text { (2 falecidos) }\end{array}$ \\
\hline marido & pai & marido & Cocama & $\begin{array}{c}2(-) \\
\left(2^{\circ} \text { onánya }\right)\end{array}$ & $\begin{array}{c}7 \\
\text { (? falecidos) }\end{array}$ \\
\hline pai & pai & $\begin{array}{c}\text { sozinha, marido } \\
\text { irmão }\end{array}$ & evangelista & $\begin{array}{c}3(+) \\
\left(3^{\circ} \text { onánya }\right)\end{array}$ & $\begin{array}{c}7 \\
\text { (4 falecidos) }\end{array}$ \\
\hline tio materno & tio materno & $\begin{array}{l}\text { sozinha, marido } \\
\text { irmão, cunhado }\end{array}$ & $\begin{array}{c}\text { católica } \\
\text { evangelista }\end{array}$ & $\begin{array}{c}3(+) \\
\left(3^{\circ} \text { onánya }\right)\end{array}$ & $\begin{array}{c}3 \\
\text { (2 falecidos) }\end{array}$ \\
\hline $\begin{array}{l}\text { tio paterno } \\
\text { marido }\end{array}$ & $\begin{array}{l}\text { pai, tios paternos, } \\
\text { mãe, tias paternas }\end{array}$ & $\begin{array}{l}\text { sozinha } \\
\text { marido falecido }\end{array}$ & $\begin{array}{c}\text { Cocama } \\
\text { evangelista }\end{array}$ & $\begin{array}{c}3(-) \\
(1-2 \text { onánya) }\end{array}$ & (4 falecidos) \\
\hline caboclo & pai & nenhum & cabocla & 2 & $\begin{array}{c}5 \\
\text { (? falecidos) }\end{array}$ \\
\hline marido & $\begin{array}{l}\text { tio materno } \\
\text { sogro }\end{array}$ & $\begin{array}{c}\text { sozinha } \\
\text { com filhos }\end{array}$ & evangelista & $\begin{array}{c}1(-) \\
\text { (onánya) }\end{array}$ & 5 \\
\hline $\begin{array}{l}\text { Mateos Mahua } \\
\text { J. Awanari }\end{array}$ & $\begin{array}{l}\text { tio materno } \\
\text { irmão }\end{array}$ & irmão falecido & Campa & 2 & 3 \\
\hline pai & $\begin{array}{c}\text { pai } \\
\text { avô paterno }\end{array}$ & $\begin{array}{c}\text { sozinha e } \\
\text { com marido }\end{array}$ & católica & $\begin{array}{c}2(-) \\
\left(2^{\circ} \text { onánya }\right)\end{array}$ & $\begin{array}{c}5 \\
\text { (2 falecidos) }\end{array}$ \\
\hline Justina & $\begin{array}{c}\text { pai, mãe, avô e tio } \\
\text { paternos }\end{array}$ & ainda não tem & católica & 2 & 6 \\
\hline mãe & $\begin{array}{l}\text { pai, tios paternos } \\
\text { mãe, avô paterno }\end{array}$ & ainda não tem & evangelista & 2 & $\begin{array}{c}2 \\
\text { (7 falecidos) }\end{array}$ \\
\hline
\end{tabular}


Mapa 1. Comunidades shipibo-conibo onde residem as mulheres onányabo

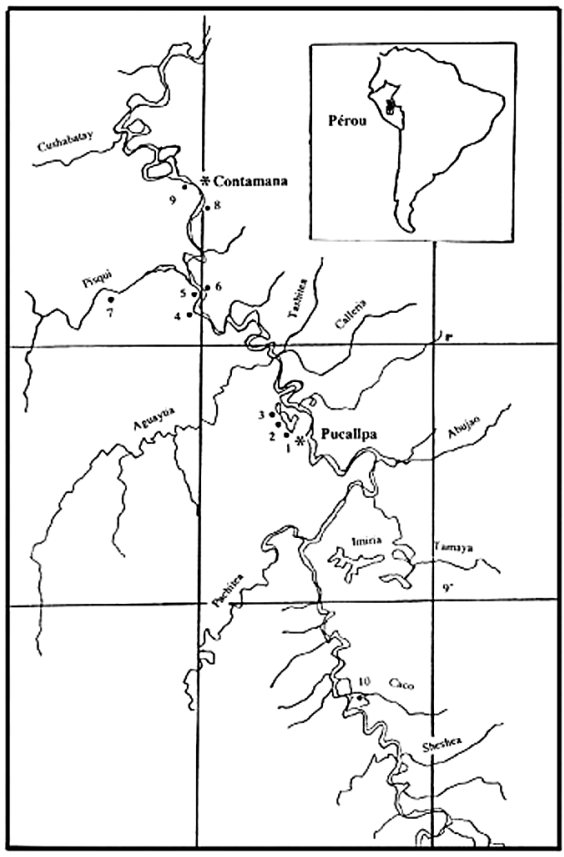

1 Vila de Yarina (Rosa e Ângela)

2 San Salvador (Isabel)

3 San Francisco (Elisa)

4 Paoyan (Maria e Manuela)

5 Santa Ana (Juana)

6 Conshanmay (Emilia)

7 Vencedor (Justina)

8 Canaan (local de permanência com Herminia)

9 Pedaço de terra de Herminia

10. Colonia do Caco (Aurora)

avançada permitia presumir só terem adquirido seus saberes após a menopausa. Todavia, duas mulheres onányabo que conheci em seguida, Emilia e Justina, ambas por volta dos quarenta anos, eram mães de crianças pequenas e conciliavam o papel maternal com aquele de onánya. Ao contrário das anteriores, eram muito consideradas pelos membros de sua comunidade, que vinham consultá-las mais que a seus maridos, igualmente onányabo. Esses casos permitiram constatar que, a exemplo do que ocorre com seus confrades homens, existem entre os Shipibo-Conibo, mulheres xamãs poderosas e outras menos influentes.

Essas mulheres onányabo não exercem seu saber com a mesma freqüência. Cinco delas (Justina, Emilia, Rosa, Isabel e Angela) conduzem sessões de consumo de ayahuasca várias vezes por semana, mas Isabel especializa-se em trabalhar para os mestiços e Angela se faz acompanhar de seu filho onánya quando trata de casos graves. Aurora, que parou de tomar a ayahuasca, resolve certos casos (roubo, agressão por projétil patogênico, amor) por meio de sonhos e saunas (saber, diz ela, proveniente dos vizi- 
nhos campa). Herminia reduziu sua atividade xamânica após a morte violenta de seu marido onánya. Ela intervém em casos urgentes ou benignos que envolvem seus parentes próximos, por exemplo, doenças infantis como a perda da alma (raté) ${ }^{14}$. Juana, ainda nos estágios iniciais, empreende certos tratamentos há pouco tempo. Maria, outrora mais ativa, preside agora menos sessões, em razão de sua idade avançada; ainda assim, está formando sua filha, Manuela. A exemplo dos homens, as mulheres onányabo podem, portanto, iniciar neófitos na arte xamânica, como faz Justina com dois noviços (um homem e uma mulher). Além disso, certos habitantes de Vencedor qualificam Justina com o título honorífico de meráya.

A partir dos dados expostos acima, alguns poderiam afirmar que poucas mulheres se dedicam intensamente à prática xamânica. Todavia, o mesmo vale para os onányabo masculinos (cf. Arévalo 1986). Tal fato não impediu, porém, a elaboração de estudos importantes sobre eles (cf. Cardenas 1989; Foller 1990; Illius 1982; Gebhart-Sayer 1986; Morin 1998). Por que deveríamos ser mais críticos diante das mulheres xamãs? Algumas delas, aliás, se mostram muito mais ativas e são objeto de maior consideração do que alguns de seus confrades masculinos.

Todas essas mulheres são (ou foram) casadas, e contam, em sua maioria, com numerosos esposos sucessivos com os quais tiveram vários filhos. A maior parte delas começou a investir no xamanismo na juventude, desde antes do casamento (Maria e Rosa) ou desde jovens (por volta de vinte anos), já com alguns filhos pequenos. Nenhuma parece considerar sua prole como um entrave ao aprendizado xamânico, já que, por ocasião da iniciação, os pequenos costumam ficar a cargo de parentes próximos ${ }^{15}$. Além disso, para justificar sua vocação xamânica, muitas mulheres invocam a possibilidade de tratar de seus descendentes. As aprendizes que têm por volta de quarenta anos (Elisa e Manuela) não chegaram ainda à menopausa, o que era igualmente o caso de Juana no princípio de sua iniciação. A atividade xamânica dessas mulheres não se explica, pois, em função do fim de sua atividade reprodutiva. O fato de que sejam relativamente maduras, entre os 37 e 69 anos, traduz, antes, um atraso na sua substituição por novas xamãs.

Essas mulheres têm todas um parente próximo onánya, seja seu pai (8 em 11), seja seu tio materno ou paterno ou, algumas vezes, sua mãe (Herminia, Manuela, Elisa). Ainda que a lembrança desses parentes seja ocasionalmente evocada como motivação para o aprendizado xamânico, seus conhecimentos não provêm sempre de seus ascendentes (6 em 11). Alguns casos à parte (Aurora, Isabel, Manuela e Elisa), a maioria vive ou já viveu com um marido onánya (7 em 11). Contudo, estes últimos não estão 
necessariamente na origem de seu saber: se algumas se iniciaram com eles (4 em 11), outras começaram a aprender antes de encontrá-los (5 em 11) e outras ainda suscitaram a prática xamânica em seus cônjuges (Justina e Emilia). Com exceção de Isabel, a maioria prefere realizar os rituais em grupo, com um parente onánya que viva nas proximidades, atualizando assim uma rede de ajuda. No entanto, o mesmo se aplica aos onányabo masculinos.

\section{Tabela 2}

\begin{tabular}{|c|c|}
\hline Mestre onánya & Aprendizes onányabo \\
\hline $\begin{array}{l}\text { Joaquin Awanari } \\
\text { (Roya) }\end{array}$ & $\begin{array}{l}\text { Maria Awanari Campos } \\
\text { (sua filha) }\end{array}$ \\
\hline $\begin{array}{l}\text { Mateos Mahua } \\
\text { (Painaco) }\end{array}$ & $\begin{array}{l}\text { Rojina Mahua } \\
\text { (sua filha) }\end{array}$ \\
\hline $\begin{array}{l}\text { Manuel Mahua } \\
\text { (Painaco) }\end{array}$ & $\begin{array}{l}\text { Maria Awanari Campos } \\
\text { (sua mulher) }\end{array}$ \\
\hline $\begin{array}{l}\text { Roberto Davila Awanari } \\
\text { (Santa Ana) }\end{array}$ & $\begin{array}{l}\text { Juana Barbaran Mondaluisa } \\
\text { (sua mulher) }\end{array}$ \\
\hline $\begin{array}{l}\text { Maria Awanari Campos } \\
\text { (Santa-Maria) }\end{array}$ & $\begin{array}{l}\text { Manuela Mahua Awanari } \\
\text { (sua filha) }\end{array}$ \\
\hline $\begin{array}{l}\text { Manuel Ochobano } \\
\text { (Conshanmay) }\end{array}$ & $\begin{array}{l}\text { Emilia Ochobano Morin } \\
\text { (sua filha) }\end{array}$ \\
\hline $\begin{array}{l}\text { Guillermo Gonsales Saldana } \\
\text { (Santa Maria) }\end{array}$ & $\begin{array}{l}\text { Giorgina Chavez } \\
\text { (sua mulher) }\end{array}$ \\
\hline $\begin{array}{l}\text { Oliviero Garcia Panduro } \\
\text { (Shanaia de Pishca) }\end{array}$ & $\begin{array}{l}\text { Camilla Mainas Munos } \\
\text { (pía: sobrinha do lado materno) }\end{array}$ \\
\hline $\begin{array}{l}\text { Sebastian Sanasino } \\
\text { (Cruzmuñona) }\end{array}$ & $\begin{array}{l}\text { Herminia Sanazino Mozombite } \\
\text { (filha de seu irmão) }\end{array}$ \\
\hline $\begin{array}{l}\text { Esteban Rodriguez Urquia } \\
\text { (Paoyan) }\end{array}$ & $\begin{array}{l}\text { Angela Raimundo Guimaras } \\
\text { (sua mulher) }\end{array}$ \\
\hline $\begin{array}{l}\text { Francisco Valera Barbaran } \\
\text { (Imiria) }\end{array}$ & $\begin{array}{l}\text { Rosa Valera Benites } \\
\text { (sua filha) }\end{array}$ \\
\hline $\begin{array}{l}\text { Justina Serrano Alvarez } \\
\text { (Vencedor) }\end{array}$ & $\begin{array}{l}\text { Atilio Mori Huayta } \\
\text { (Conibo casado com um mulher de Vencedor) }\end{array}$ \\
\hline $\begin{array}{l}\text { Camilla Mainas Munos } \\
\text { (Libertador) }\end{array}$ & $\begin{array}{l}\text { Anita Fernandez Mainas } \\
\text { (parente do lado materno) }\end{array}$ \\
\hline
\end{tabular}


Muitas onányabo femininas fizeram seu aprendizado junto aos mesmos mestres (cf. Tabela 2), o que poderia levar a crer estarmos diante de alguns excêntricos que teriam decidido ensinar mulheres. Todavia, casos isolados, em que um marido inicia a esposa ou um pai a filha, parecem contradizer esse ponto de vista. Duas mulheres (Isabel e Elisa) não obtiveram seu saber de parentes próximos - fato bastante excepcional, visto que a desconfiança

\begin{tabular}{ll}
\hline $\begin{array}{l}\text { Joaquina Awanari Campos } \\
\text { (sua filha) }\end{array}$ & $\begin{array}{l}\text { Aurora Carion Canayo } \\
\text { (filha da irmã da mulher) }\end{array}$ \\
\hline $\begin{array}{l}\text { Aurora Carion Canayo } \\
\text { (parente de Rojina Mahua) }\end{array}$ & \\
\hline Anita Fernandez Mainas & $\begin{array}{l}\text { Manuela Mahua Awanari } \\
\text { (sua concubina) }\end{array}$ \\
\hline $\begin{array}{l}\text { Manuela Mahua Awanari } \\
\text { (sua prima) }\end{array}$ & $\begin{array}{l}\text { Emilia Ochovano Morin } \\
\text { (parente de sua mulher) }\end{array}$ \\
\hline
\end{tabular}

Camilla Mainas Munos

(pía: filha de sua irmã)

Justina Serrano Alvarez

(pía: filha de sua prima)

Herminia Sanazino Mozombite

(sua mulher)

Elisa Vargas Fernandez 
rege, em geral, as relações entre onányabo. A propósito de influências exógenas, alguns testemunhos fazem referência aos conhecimentos xamânicos dos vizinhos cocama (Justina, Herminia); outros, ao saber dos Campa (Aurora). Mesmo que Isabel tenha sido iniciada por um mestre mestiço, o saber de todas essas mulheres traduz complexas idas e vindas entre vários sistemas de crenças. A maioria inclui em seu aprendizado livros que se vendem nas cidades, como o Tarô, e a utilização de preces. Algumas onányabo se dizem católicas, outras evangélicas e nenhuma parece ver contradição na reprovação que essas religiões dirigem a suas práticas. Uma vez que a maior parte delas foi guiada em sua iniciação por um mestre onánya masculino, seus conhecimentos se aproximam mais do saber deste homem que daquele de uma onánya rival. O percurso iniciático de cada um parece, assim, ter uma maior incidência sobre a elaboração do saber xamânico do que o gênero do oficiante. Uma tal afirmação será corroborada adiante, quando for explicitada a forma de aquisição de poderes xamânicos entre os Shipibo-Conibo.

\section{O papel do ambiente na constituição do xamã}

Para compreender o xamanismo shipibo-conibo, devemos necessariamente nos referir ao ambiente. Diversos mitos identificam a fonte do poder e conhecimento - cosmológico, tecnológico, terapêutico - aos ráo. Esse termo remete sobretudo às plantas (95\% segundo Tournon 1991b) que possuem um poder particular, modificando o comportamento humano (veneno, alucinógeno, medicamento, perfume etc.), mas se aplica também a alguns produtos animais, minerais, e mesmo a certos objetos que realizam os mesmos fins ${ }^{16}$. Os Shipibo-Conibo não estabelecem fronteiras estanques entre os reinos — vegetal, animal, mineral, humano — , mas os consideram antes como estando em continuidade: eles se influenciam e interpenetram em virtude de uma comunidade de substância. Os ráo contribuem para a formação do corpo shipibo-conibo, que não cresce "naturalmente", como no modelo biológico, mas que deve ser constantemente "construído" por uma série de procedimentos precisos ${ }^{17}$. Por exemplo, antes do nascimento, o sexo de um bebê pode ser provocado por vegetais cujos atributos evocam as partes genitais masculinas ou femininas, e, desde sua chegada ao mundo, os bebês se fortalecem graças às virtudes dos ráo dos quais eles obtêm qualidades valorizadas como a inteligência, por exemplo. Durante a infância, os ráo estimulam o aperfeiçoamento de capacidades sociais: previnem contra a preguiça (rayáti ráo), "ensinam" aos rapazes a arte da caça (métxati ráo) e às moças a do artesanato (kéneti ráo). Regulam os compor- 
tamentos censuráveis, como a agressividade (tánti ráo), a avareza (yóaximati ráo) ou a sexualidade excessiva (tsínix ráo). Resolvem também carências corporais: uma insuficiência de leite materno ou de esperma se soluciona com a utilização de certas seivas brancas.

Tudo isso pode parecer paradoxal para um observador ocidental, na medida em que é o meio, notadamente as plantas, que contribui para "humanizar" o ser humano, fornecendo a este os elementos necessários à sua constituição específica. Isso se explica, todavia, pelos conceitos de "socialização do vegetal" (Barrau 1990) e de socialização do ambiente (Descola 1986): os Shipibo-Conibo consideram que os ráo possuem suas "gentes" (ráo jónibo), entidades que não apenas assumem a aparência de pessoas, mas o são realmente, e que intervêm em favor dos humanos quando seu suporte é manipulado - por ingestão, emplastro, sauna, banho - e quando certos tabus são respeitados. O onánya maximiza essas práticas corporais para assimilar de maneira mais significativa as características dos mestres dos ráo (ráo íbo). Por meio do jejum e da inatividade (kikín samá), ele se torna fraco e permeável aos odores dos ráo, veículos de suas propriedades medicinais, patogênicas, de atração e outras. Se todos podem usufruir dos benefícios dos ráo, os onányabo são os únicos que buscam uma identificação profunda com suas "gentes", que contatam voluntariamente por intermédio de sonhos e alucinógenos, principalmente a ayahuasca. Eles iniciam então aos cantos xamânicos (onányati bewá), vetores do poder dos ráo e códigos de comunicação por excelência entre os onányabo e seus auxiliares.

A utilização dos ráo se revela, em compensação, delicada, e a transformação que eles produzem pode ser irreversível. Diversas narrativas shipibo-conibo ilustram tais transmutações: após o grande dilúvio mítico, os onányabo submersos se metamorfosearam em vegetais poderosos (kóxi ráo); uma planta utilizada como encantamento amoroso (nomán wáste) foi, inicialmente, uma mulher muito bela que sabia seduzir os homens. Nessa mesma ordem de idéias, os Txáiconibo - seres imaginários aos olhos de um observador ocidental, mas considerados bastante reais pelos Shipibo-Conibo — são descritos como ancestrais que adquiriram suas qualidades excepcionais graças à utilização de uma árvore poderosa (níwe ráo) à qual se identificam desde então de maneira fusional, pois são designados como suas "gentes" (níwe ráo jónibo). Os Txáiconibo encarnam o modelo de uma sociedade ideal: mestres dos animais, possuem uma habilidade sem igual na caça e na pesca; exibem um caráter trabalhador e uma força extraordinária; são qualificados de generosos, belos e odoríferos. Além disso, os Txáiconibo consideram os humanos empesteantes e, por esse motivo, vivem escondidos na floresta, mantendo-se invisíveis por meio da utilização de plantas aromáticas ${ }^{18}$. Para conseguir 
contatá-los, os onányabo devem banhar-se com as folhas da árvore níwe ráo e respeitar severos tabus. Tentam, assim, adquirir suas características — perfume, força, beleza - para tornarem-se, à sua imagem, super-humanos.

A iniciação xamânica entre os Shipibo-Conibo concerne principalmente à faculdade de se identificar ao domínio dos ráo. Estes últimos dão forma ao corpo do aprendiz, independente de seu sexo: o tornam robusto (kóxi), odorífero (inín), inteligente (onán), curativo (ráo) e assim por diante, segundo o caso. Para determinar a força de um onánya, o que se enfatiza não é o fato de tratar-se de um homem ou de uma mulher mas, antes, sua aptidão em obter o conhecimento, isto é, a capacidade de conjugar a utilização de ráo potentes e o respeito pelos interditos alimentares e comportamentais (kikín samá), que neutralizam as secreções humanas mal-cheirosas (flatulência, suor, esperma, menstruação etc. ${ }^{19}$. As práticas corporais restritivas e a intervenção do ambiente permitem assim às mulheres limitarem suas secreções e maus odores para tornarem-se similares a seu ideal txáiconi. Os Txáiconibo são, ademais, exemplo de como os ancestrais shipibo-conibo de ambos os sexos transformaram-se em super-humanos graças à manipulação da árvore níwe ráo.

O meio participa de maneira constante na formação dos corpos dos homens e das mulheres, principalmente no caso dos xamãs. Uma tal concepção da corporalidade não pode ser reduzida às noções ocidentais, que concebem o ser humano - e mais particularmente a mulher - como limitado por sua biologia. Assim como seus homólogos masculinos, as mulheres onányabo podem aperfeiçoar-se corporalmente até atingir os estados superiores de saber. Elas não são concebidas, por suas funções reprodutivas, como mais próximas da "natureza" - um tal conceito não faz sentido em uma sociedade onde os seres humanos vivem em continuidade e interação com seu meio socializado. O xamanismo shipibo-conibo não opõe o homem e a mulher de maneira dicotômica, uma vez que faz intervir um terceiro termo, o ambiente, processo relacional que nada tem a ver com uma concepção essencialista de gênero.

Alguns exemplos dados a seguir vão demonstrar como as mulheres onányabo podem adquirir os mesmos poderes que seus confrades. Os casos apresentados concernem a papéis comumente considerados masculinos na área amazônica: o controle da sexualidade, a caça e o xamanismo ofensivo/defensivo. Como certos ráo detêm esses conhecimentos (respectivamente, nói ráo, métxati ráo e yobéji ráo), eles podem transmiti-los às mulheres se estas obedecerem aos tabus apropriados. Os testemunhos das mulheres onányabo tornam assim possível uma crítica de certas generalizações antropológicas que repartem de maneira excessivamente sistemática um saber masculino em oposição a um saber feminino. 


\section{Controle da sexualidade e da vida familiar}

Diversos estudiosos, falando da região amazônica, atribuíram aos homens a exclusividade sobre os encantamentos que permitem o controle da sexualidade. Uma tal dedução emana, em grande parte, da seguinte teoria: já que o homem não possui a capacidade feminina da gestação, ele se apropria da reprodução cósmica e rege a sexualidade das mulheres (entre outros, Lorrain 2000 e Bellier 1991). Assim, no que se refere à sedução, a literatura sobre a área amazônica assimila freqüentemente a mulher à caça — empregam-se as mesmas plantas, argumenta-se, para atrair tanto uma como a outra. Para os Shipibo-Conibo, ainda que tal afirmação não seja falsa — ela corresponde sobretudo ao discurso formulado por certos locutores masculinos - ela se revela todavia incompleta. Quando levamos em conta a versão feminina, vemos que as mulheres empregam os mesmo sortilégios para seduzir os homens ${ }^{20}$.

As mulheres onányabo obtêm o saber de atração junto aos nói ráo (nóiti = "amar"), dotados de certos atributos particulares - como o odor agradável e/ou a capacidade de se enroscar tal qual o cipó - que indicam seu poder: epífito que cresce enrolando-se em torno de uma grande árvore e termina por sufocá-la; árvore que possui diversos troncos unidos por uma cadeia de folhas ovais; erva de perfume inebriante ${ }^{21}$. Os mestres desses vegetais (nói ráo íbo) ensinam os cantos xamânicos (nésha bewá; néshati = atar) que permitem influenciar os comportamentos amorosos de homens e mulheres. Diversos onányabo afirmam que esse tipo de tratamento é dos mais lucrativos, pois numerosos mestiços o solicitam. Ora, os casais shipibo-conibo com problemas amorosos também costumam fazer referência ao onánya (geralmente em segredo). Assim, um homem de Vencedor (junho de 2001), abandonado por sua esposa, consultou Justina: ele conta com esta onánya cujas competências exalta para fazer retornar sua companheira.

Para evitar conflitos sociais, alguns onánya dissimulam os comportamentos censuráveis cometidos por seus parentes próximos. Muitos optam pela discrição e, por ocasião dos rituais, cantarolam de maneira esotérica, empregando uma linguagem desconhecida da audiência (como o quechua ou o cocama). O onánya pode, todavia, manifestar um comportamento contrário, segundo sua personalidade, seu envolvimento com os membros de sua comunidade e os diferentes contextos. Justina (em 2000-2001), que é aparentada da maioria dos habitantes de Vencedor, entoava freqüentemente, durante as sessões de consumo da ayahuasca, cantos bastante explícitos que desvendavam para os ouvintes as ações embaraçosas dos interessados. Ela insinua, por exemplo, que uma criança sofre de "contágio do coito" (txotáti copía) porque seus pais infringiram o tabu sexual da couvade; ou, ainda, 
que as aflições recorrentes de um jovem rapaz devem-se a suas múltiplas infidelidades. Tais afirmações causam o riso geral entre os presentes e relaxam a atmosfera da cura, mas exercem também um papel de censura sobre os responsáveis, que se sentem incomodados (rabíntí). Tornando públicos os comportamentos inadequados, essa onánya impõe um certo controle social.

Embora afirmem utilizar seus poderes sobre questões amorosas apenas quando explicitamente solicitados, os onányabo também lançam mão de seus conhecimentos em vantagem própria. Assim, um homem onánya praticava ainda, há uma década, a poligamia sororal. Ele dirigira "cantos de amor" a suas duas mulheres para que elas se entendessem bem e permanecessem "atadas" a ele. As mulheres onányabo se indagam quanto à vida sentimental de seus esposos e tentam, por encantamentos-cantados, influenciar seus comportamentos. Por isso, alguns maridos temem que suas esposas se iniciem ao xamanismo, como admite o onánya Roberto (de Santa-Ana, 2000), que limita expressamente o aprendizado de sua mulher Juana. Diversos onányabo têm a reputação de serem grandes sedutores, pois a abundante utilização de plantas requerida pelo aprendizado xamânico os faz perfumados, permitindo-lhes encantar tanto os seres da floresta, quanto os humanos. Uma onánya, com ciúmes das conquistas provocadas pelo saber de atração de seu marido xamã, o despossuiu de certos poderes que recuperou para si própria ${ }^{22}$. A partir deste episódio, tendo-se tornado especialista na matéria, o adultério já não lhe causa mais temor, pois confessa conhecer cantos específicos - soprados de maneira inaudível com a fumaça do tabaco - que lhe permitem reger as ereções de seu esposo: o "canto da minhoca" (sháco bewá) ${ }^{23}$ — verme que se retorce quando tocado - e o "canto do jabuti" (manánshawe bewá) animal reputado por sua moleza e lentidão. Ao discurso da interessada, acrescentemos o das jovens da comunidade, que consideram perigoso responder aos avanços do marido sedutor, por temer o castigo dessa praticante renomada ${ }^{24}$. O simples fato de possuir um tal estatuto confere, pois, a essa onánya, um certo controle sobre sua vida conjugal e sobre a sexualidade dos que a cercam. Os onányabo também empregam suas competências para manipular seus familiares. Assim, segundo Herminia (Canaan, julho de 2001), seu filho adotivo (onán báke), de trinta anos, "esquecera" sua intenção de partir para a cidade graças a um canto que "o liga a ela", e, segundo Juana (Santa-Ana, junho de 2000), se todas suas filhas moravam com ela, era por causa dos encantamentos-cantados que "atavam" seus genros a sua comunidade.

O saber de sedução parece, por definição, inseparável de seu contrário, o saber de repulsão (pétxi), pois, para encantar e atrair uma pessoa, esta úl- 
tima deve, freqüentemente, depreciar ou esquecer alguma outra (cônjuge ou familiar). Os onányabo calam-se, em geral, sobre esse duplo aspecto para não serem associados ao feiticeiro. Entretanto, um mesmo ráo concede, muitas vezes, esse duplo conhecimento. Justina conta em seu repertório xamânico com o "canto do urubu" (poínkosco bewá), pássaro considerado repugnante. Atingida por este encantamento, a vítima se converte na imagem do carniceiro: ela não cuida mais de sua aparência e recusa-se a trabalhar, dessa forma despertando nojo em seus pares, que terminam por abandonála. Segundo Justina, esses cantos defensivos permitem tratar casos de sexualidade excessiva (tsínia), resultado de maldições. Ela comenta que os feiticeiros mestiços de aldeias vizinhas utilizam esses encantamentos-cantados para perturbar o pensamento das moças e abusar sexualmente delas. Assim, por ocasião de uma sessão de consumo de ayahuasca, ela viu a cabeça de uma jovem lasciva recoberta de uma "coroa mal-cheirosa em forma de arraia" (íwi máiti), touca do boto coxóxca que torna a pessoa libidinosa à sua imagem. Os sentimentos passionais são também explicados como conseqüência de sortilégios amorosos (no espanhol regional, pusanga) - uma pessoa que subitamente se apaixona por outra é dita vítima de um encantamento e não é tida como responsável por seus atos. Por exemplo, uma mulher, por duas vezes, deixou seu marido por homens diferentes. A cada vez, o diagnóstico do onánya, ninguém mais que seu sogro, revela que ela foi enfeitiçada por plantas de amor nói ráo. Como a planta agiu à sua revelia, a mulher foi perdoada por seu esposo.

As mulheres onányabo sabem também tratar pessoas violentas e de temperamento impetuoso, por meio de plantas tánti ráo (acalmar/ráo), cujos "mestres afetuosos" transmitem os cantos necessários para isso (tánti bewá). Assim, Herminia obteve o "canto da tartaruga" (copitso bewá) que converte o violento em pacífico. Todavia, ela sustenta que é preciso dosar bem este canto, ou a pessoa se torna dócil demais, e até mesmo bonachona. Os onányabo podem igualmente moldar os gostos e hábitos de vida de seus próximos, como ilustra o tratamento contra a repulsa ao tabaco. Segundo os onányabo, a fumaça do tabaco afasta os seres nocivos do ambiente. Em conseqüência, eles julgam suspeita toda pessoa que não goste de fumar. Graças ao "canto do tabaco" (róme bewá), Justina transmitiu esse hábito à sua cunhada, que agora a auxilia nos tratamentos xamânicos fumando a seu lado.

Segundo os Shipibo-Conibo, os onányabo possuem todos, pois, um poder considerável, e isso independentemente de seu sexo: eles controlam certos comportamentos reprovados, que vão da simples repulsa ao tabaco à agressividade ou sexualidade excessivas. A importância concedida aos conhecimentos de questões amorosas não deve ser subestimada: em uma 
sociedade onde a política está ligada ao parentesco e onde as esferas públicas e privadas se confundem, intervir junto aos familiares pode impedir discórdias importantes. Dado que a aliança intergrupal se concretiza o mais freqüentemente por meio de casamentos, manipular disputas amorosas confere aos onányabo um papel considerável. Além disso, a regulação desses conflitos é por vezes feita segundo seus próprios fins, atraindo familiares específicos e afastando rivais. Por exemplo, na contramão do princípio matri-uxorilocal shipibo-conibo, Justina reúne em torno de si seus irmãos e primos patrilaterais, cercando-se de aliados influentes. Para além de atuar sobre simples conflitos amorosos, as mulheres onányabo podem jogar, elas também, nos grandes tabuleiros do poder social e político.

\section{Favorecer a caça}

Uma vez que, na Amazônia, a caça é uma ocupação que cabe geralmente aos homens, parece lógico presumir que apenas os onányabo masculinos intervenham nesse domínio. Ora, os Shipibo-Conibo consideram que certas plantas favorecem a caça (métxati ráo) e outras permitem o contato com os mestres da caça, os Txáiconibo. Como as mulheres onányabo se iniciam junto a esses vegetais, elas não ignoram os saberes neles implicados. Antes de explicitar esse ponto, exploremos algumas noções referentes à caça, atividade que também pode explicar-se em termos de sedução.

Já que o resultado de uma caçada depende da boa vontade dos mestres dos animais, o sucesso significa que o caçador está sob as boas graças destes últimos, ou seja, que eles se dispuseram a deixar os animais saírem de seus "cercados" e colocaram-nos no caminho do caçador. Como a caça não é considerada uma questão de sorte, o caçador procura tornar-se favorável aos Txáiconibo, para quem os humanos cheiram mal. Ele adota, pois, tabus severos para livrar-se dos odores corporais pestilentos que o tornam preguiçoso e inábil (yópa), e se perfuma com banhos e saunas de plantas aromáticas. As mulheres podem acompanhar os maridos à caça, e participam também na captura de jabutis e pequenos animais mas, estando em questão o odor, evitam essas excursões durante o período menstrual ou pósparto, quando são consideradas mal-cheirosas. Nesse aspecto, as mulheres onányabo podem constituir exceção: por meio de períodos de severas restrições e da utilização abundante de certas plantas, elas tornam seu sangue menstrual perfumado e inofensivo (caso de Justina). As práticas corporais próprias à iniciação xamânica favorecem os onányabo em relação aos mestres da caça, independentemente de seu sexo: eles possuem a 
"aura benéfica" (jakón néte) que agrada os Txáiconibo. Recordemos que as plantas que ensinam a encantar os humanos (nói ráo) são, muitas vezes, as mesmas que permitem atrair os animais (métxati ráo) ${ }^{25}$. Este fenômeno, observado em diversas sociedades amazônicas, levou certos autores a associar o caçador e o xamã em oposição à mulher e à presa. Ora, tal como sustentado acima, a sedução entre os Shipibo-Conibo não é unissexuada. Como as mulheres onányabo incorporam os odores benéficos dos vegetais, elas seduzem tanto os homens como a caça. Aliás, o marido de Justina a convida freqüentemente para caçar, pois o laço privilegiado que esta onánya mantém com os Txáiconibo lhe permite atrair as presas.

As mulheres onányabo podem intervir junto aos caçadores e favorecer sua sorte, sobretudo se elas se iniciaram nos encantamentos de caça. Assim, pelo aprendizado junto à árvore txóa (ráo não-identificado), Herminia (Canaan, julho de 2001) adquiriu o "canto do martim-pescador" (tsonkíro bewá), pássaro dito métxa, isto é, bom caçador ${ }^{26}$. Por intermédio de um ritual de consumo da ayahuasca, Herminia dirigiu este canto a seu neto, conferindo-lhe a habilidade do pássaro sob a forma de arco e flechas invisíveis (kanoti pía páoti), tornando-o, assim, "paramentado" (ráota) para a caça $^{27}$. Da mesma maneira, a árvore ínoashatan (Couropita amazonica) concedeu-lhe o "canto da onça preta" (wíso íno bewá), que ela dedicou a este mesmo neto para transmitir-lhe a força do animal, cobrindo-o desta feita com uma banda peitoral que toma a forma de uma larga veia de jaguar invisível (íno póno páoti). Para que esses cantos sejam eficazes, a pessoa a qual eles se destinam deve respeitar tabus severos, ou conseqüências danosas se seguirão. Por exemplo, Justina (Vencedor, setembro de 2001) dirigiu um "canto do caititu" (jóno bewá) a seu sobrinho que, com essa vantagem, capturou três belas presas, mas conseguiu trazer apenas duas ao passo que, entrementes, carniceiros devoraram a carcaça abandonada na floresta. A podridão poluiu então a carne encantada; ela maculou o poder de Justina, de agora em diante ineficaz e pôs o sobrinho gravemente doente. Enquanto, na maior parte dos casos, as intervenções dos onányabo amplificam a destreza do caçador, Justina é capaz também de seduzir certos seres do ambiente: ela dedica cantos aos "deuses dos jabutis e dos caititus" (manánshawe riós/jonón riós) para que, assim encantados, ofereçam seus homólogos aos caçadores. Muitos homens consultam Justina para que ela lhes sopre esses cantos com a fumaça de tabaco. Esses exemplos são uma demonstração do papel inegável das mulheres onányabo no domínio da caça. 


\section{Competência de yobé}

Do mesmo modo que o saber associado à caça, a competência de yobé implica um modo de agressão ofensivo/defensivo e a utilização de "flechinhas" invisíveis (yotó), conhecimento que evoca o papel masculino de caçador-guerreiro e que se poderia supor, portanto, caber exclusivamente aos homens. No entanto, excetuando-se o caso de Juana (iniciada por seu marido onánya, não sem temores de que ela obtivesse demasiado poder nesse domínio), todas as mulheres onányabo que encontrei sabiam como extrair os agentes patogênicos do corpo do paciente (yotóa; no espanhol regional, chonteado) ${ }^{28}$ e, conseqüentemente, como agredir por seu intermédio. Como mencionado acima, o termo yobé designa tanto o especialista nos dardos xamânicos quanto o feiticeiro, sendo um termo ambivalente que também é aplicado nesses dois sentidos às mulheres onányabo. Assim, Herminia se isola em sua roça, pois muitos habitantes da comunidade de Canaan, onde residem seus familiares, a consideram uma feiticeira. Como todos os seus filhos faleceram, as más-línguas insinuam que ela os concedeu como alimento a seus auxiliares jaguares (ínoyoxin). A designação yobé assume, nesse caso, um sentido muito negativo.

A iniciação xamânica shipibo-conibo envolve o acúmulo de uma substância, que se forma a partir da saliva e se materializa em uma flegma espessa e grudenta nomeada keyón, matriz a partir da qual se constituem os dardos. Justina conta que recebeu sua primeira flegma extraída da boca de seu mestre onánya (seu falecido tio materno), que lhe legou o keyón do conjunto de seu aprendizado. Em seguida, ela acumulou a flegma de vários ráo, entre eles a potente flegma do pica-pau (boín), que ela aspirou pelo bico do pássaro. O pica-pau se alimenta de vermes alojados em árvores grossas, "sua língua possui a força para retirá-los" (jawén jána mea kóxi tsékay). À imagem dele, Justina realiza sucções durante as curas e é capaz de extrair do corpo do paciente uma prova tangível do mal, como um pequeno inseto ou pedaço de madeira. Ao contrário da maior parte dos homens e mulheres onányabo encontrados, ela não retira apenas "o ar do agente patogênico" (yotó níwe), mas o próprio agente, o que aumenta sua reputação.

Além de demonstrar que certas mulheres onányabo detêm o saber de yobé, esse exemplo mostra que elas se iniciam, por vezes, junto a certos animais. Alguns onányabo afirmam que os animais não são capazes de ensinar porque não possuem propriedades medicinais (ráo): eles são apenas alimento (non pití) ${ }^{29}$. Seu sangue aparece como uma substância patogênica quente e mal-cheirosa. No entanto, diversas partes corporais de animais servem de ráo, como o coração do periquito (báwa), que é administrado aos avaros, o cérebro do pássaro japu, que favorece a inteligência, e a remela 
do martim-pescador (tsonkíro), que permite à pessoa tornar-se um hábil caçador. Alguns animais não comestíveis também podem comunicar seu saber ao onánya; os mais citados são o pássaro txíshca, a lontra (bonsín), o poraquê (kóni), a sucuri (ronón ewa) e o jaguar (íno). Eles transmitem sobretudo suas defesas; por exemplo, o poraquê veicula suas propriedades elétricas e o jaguar, sua ferocidade. Aprender com esses animais - objeto de proibições alimentares por causa de seus costumes suspeitos - é freqüentemente considerado arriscado e perigoso. Assim, em troca de suas qualidades, o jaguar exige presas humanas. Se o onánya as recusa, ele pode então devorar seus familiares (caso tido como sendo o de Herminia) ou até mesmo o próprio onánya. A maior parte dos onánya oculta, pois, esse tipo de saber, para não ser acusado de feiticeiro.

No entanto, além de Justina, Emilia (Conshanmay, junho de 2000) também afirma abertamente ter aprendido com o pássaro txíshca, trazido de uma caçada por seu irmão. Ela aplicou sobre seus próprios olhos a remela do pássaro, tornando-se, assim, capaz de tudo ver/saber, sem ter de apelar à ayahuasca. Pelo bico do pássaro, aspirou também sua flegma amarga, que lhe permite tratar eficazmente pessoas atingidas por flechas patogênicas. Essa onánya, que não se identifica como yobé, possui auxiliares percebidos por outros como tais (como o jaguar e a lontra), o que ilustra o caráter contextual de um saber que se mostra benéfico (jakón) quando é "seu, próprio", e maléfico (jakónma) quando é "outro, distinto".

O arsenal xamânico e as estratégias defensivas das mulheres onányabo se revelam tão sofisticados quanto os de seus confrades masculinos: elas possuem armas e escudos invisíveis, freqüentemente bastante modernos (fusis, aviões, torres). Existem rivalidades entre onányabo - homens e mulheres - desmentindo a idéia de que as mulheres xamãs podem apenas curar, sem tomar parte dos enfrentamentos xamânicos (Perrin 1995). Um tal conceito não faz sentido entre os Shipibo-Conibo, onde a "doença" é geralmente concebida como uma agressão externa à qual o onánya deve responder. Visto que as sessões de cura se assemelham, o mais das vezes, a combates guerreiros, as mulheres onányabo estão preparadas para os ataques que têm lugar durante as sessões de consumo da ayahuasca.

\section{Conclusão}

Os estudos de caso aqui desenvolvidos demonstram como as mulheres shipibo-conibo podem adquirir poderes xamânicos consideráveis quando se iniciam junto a certos vegetais ou animais poderosos, e como podem intervir 
em domínios correntemente considerados masculinos, na área amazônica (a sedução, a caça e a agressão). Para compreender a possibilidade de uma tal prática xamânica, é preciso remeter a uma concepção particular do mundo: os Shipibo-Conibo não pensam a natureza como uma realidade objetiva e externa, referindo-se antes a um ambiente socializado, encarnado por mestres (notadamente, os Txáiconibo) com os quais interagem segundo seus próprios modelos sociais. Mais do que simples metáforas, essas relações são consideradas reais e são possibilitadas por um trabalho corporal constante: o ambiente modela o corpo humano a ponto de torná-lo similar àquele dos seres da floresta. As noções de ambiente socializado (Descola 1986; 1992) e de corporalidade maleável (Viveiros de Castro 1998) contrastam com as idéias ocidentais, que concebem o homem como destacado de seu ambiente e a mulher como limitada por sua biologia. O xamanismo shipibo-conibo não opõe homem e mulher de maneira dicotômica, fazendo, antes, intervir um terceiro termo, o ambiente. Este último permite uma identificação com os seres da floresta independentemente do sexo do interessado, do que deriva a possibilidade de praticantes femininas.

$\mathrm{O}$ fato de mulheres xamãs influentes terem sido identificadas em uma sociedade na qual sua presença era omitida, ou mesmo dita inexistente, levanta a possibilidade de encontrarmos um xamanismo feminino de importância comparável em outras partes da Amazônia. Uma vez que certas populações amazônicas parecem partilhar noções similares de ambiente socializado e corporalidade maleável, quem sabe algumas dentre elas não permitiriam também a emergência de mulheres xamãs? Esse artigo não pretende extrapolar, a partir do caso estudado, uma atividade xamânica feminina para o conjunto das sociedades amazônicas, reconhecendo a variedade das manifestações xamânicas na região e a presença de diferentes especialistas com poderes diversificados no interior de uma mesma sociedade. Não obstante, alguns poderiam querer restringir a possibilidade de um xamanismo feminino aos Shipibo-Conibo, com base no lugar privilegiado ocupado pelas mulheres nessa sociedade ${ }^{30}$. Como, então, interpretar a evidência etnográfica da existência de mulheres xamãs em populações amazônicas onde as relações de gênero parecem mais coercitivas, como no caso dos Achuar (Robert Crépeau, com. pessoal) ou dos Yanomami (Alès 1998)? A pobreza de dados etnográficos relativos a essas mulheres (dados que provirão, de preferência, das mulheres xamãs elas mesmas, e não do que se diz a seu respeito), impede, por enquanto, qualquer generalização concernente a suas práticas xamânicas.

Como foi sublinhado no início deste artigo, a etnologia amazônica não nega a existência de mulheres xamãs; ela divulga, todavia, informações 
muito escassas a seu respeito. A pouca importância numérica das mulheres xamãs serviu freqüentemente de argumento para considerá-las não representativas, e para excluí-las a priori de descrições etnográficas mais finas. Ora, o fato de que essas mulheres sejam minoritárias justifica tratá-las como casos negligenciáveis, que não merecem ser estudados? A importância conceitual de um fenômeno pode ser medida em termos estatísticos? Os homens onányabo são majoritários, certamente, mas isso não impede a existência de mulheres xamãs influentes entre os Shipibo-Conibo. Ignorar essas mulheres conduz a formar uma imagem distorcida do xamanismo shipibo-conibo como prática exclusivamente masculina. Em lugar de nos deixarmos guiar por questões quantitativas, parece mais interessante abordar o que significa, para a compreensão do fenômeno xamânico na Amazônia, a presença ou ausência de mulheres xamãs - com poderes e práticas variáveis - nas diferentes sociedades da região. O estudo do xamanismo à luz das mulheres visa, assim, estimular uma reflexão em torno da riqueza e complexidade das manifestações xamânicas na Amazônia.

Recebido em 15 de janeiro de 2005

Aprovado em 10 de fevereiro de 2005

Tradução de Marcela Coelho de Souza

Anne-Marie Colpron é pós-doutoranda no PPGAS/ Museu Nacional/ UFRJ e pesquisadora do Núcleo Transformações Indígenas (NUTI). E-mail: <anacolpron@hotmail.com> 


\section{Notas}

* Gostaria de agradecer a Eduardo Viveiros de Castro por seus comentários a uma versão anterior deste artigo. Igualmente, agradeço em especial a Marcela Coelho de Souza pela tradução e a Flávio Gordon pela revisão final.

${ }^{1}$ O termo genérico "xamã" é posto entre aspas para sublinhar a "desconcertante diversidade" (Hamayon 1982:13) do fenômeno, que varia no espaço segundo as várias populações que o praticam (por vezes, encontram-se na mesma sociedade diferentes especialistas xamãs) - e no decorrer do tempo, adaptando-se ao curso da história (para uma discussão detalhada do termo "xamã", ver Colpron 2004). Ao apresentar os diversos especialistas shipibo-conibo, suas próprias denominações serão utilizadas para sublinhar a singularidade de seus saberes e práticas.

2 Esse trabalho de campo foi realizado durante minha pesquisa de doutorado, de maio a outubro de 2000 e de junho a novembro de 2001, graças a uma bolsa do Fonds pour la Formation de Chercheurs et l'Aide à la Recherche do Québec.

${ }^{3}$ Esta explicação, entenda-se, não é a única em causa. Uma outra fonte de confusão pode ser atribuída a dados contraditórios obtidos em campo: muitos shipiboconibo negavam, eles mesmos, a existência de mulheres xamãs, problema analisado alhures (ver Colpron 2004).

${ }^{4}$ Embora construam diferentemente sua argumentação, esses autores chegam à mesma conclusão. Assim, segundo Lorrain (2000:305), já que o homem não possui a capacidade feminina de gerar, ele se apropria da reprodução cósmica e controla a sexualidade feminina: "é fundamentalmente uma fraqueza masculina, em lugar de uma fraqueza social feminina, que constitui o nexo da cosmologia de gênero, econômica e política". A referência à incapacidade biológica masculina remete, entretanto, ao papel reprodutivo particular da mulher, e não permite considerar as relações de gênero senão através da diferença biológica. Jackson (1992), por sua vez, adota uma abordagem psicanalítica: ela explica o controle masculino das esferas políticas e religiosas pelo temor diante da sexualidade feminina. Para uma demonstração com o apoio das referências, ver Colpron (2004:4-55).

${ }^{5} \mathrm{O}$ título "Comunidade Autóctone" é almejado pelos Shipibo-Conibo, pois lhes confere um direito inalienável sobre suas terras. Paradoxalmente, os circunscreve em um território delimitado em um contexto de crescimento demográfico. 
${ }^{6} \mathrm{O}$ xamanismo feminino shipibo-conibo não se encontra, pois, em um contexto onde os homens abandonam a prática xamânica, como entre os Guajiro (Perrin 2001), os Mapuche (Bacigalupo 1998), os Puyuma (Cauquelin 2000) ou os Toungouse (Hamayon 1994).

${ }^{7}$ Ayahuasca é o nome de origem quechua de um cipó alucinógeno (Banisteriopsis caapi) que os Shipibo-Conibo nomeiam níxi óni. Esse cipó é misturado às folhas do arbusto chacruna (Psychotria viridis, cáwa em shipibo-conibo), que causa a embriaguez por ocasião dos rituais xamânicos.

${ }^{8}$ Em atenção ao diálogo com os colegas panólogos brasileiros, este artigo adota a transcrição brasileira das línguas pano, e não a ortografia espanhola proposta no dicionário shipibo-espanhol (Loriot et alii 1993). Assim, o "sh" é substituído por " $\mathrm{x}$ "; o "ch" por "tx"; o "sh" com trema sobre "s", por "sh"; o "qu" por "k" e o "hu" por "w".

${ }^{9}$ De acordo com certos Shipibo-Conibo, não existem mais meráya vivos. Uma tal afirmação não constitui, porém, unanimidade; alguns habitantes de Vencedor qualificam sua xamã Justina como meráya.

10 Podemos nos perguntar sobre a influência missionária na diabolização do yobé.

${ }^{11}$ Huesero é um termo em espanhol regional, usado para designar um tipo de "quiroprático" local. Para uma descrição mais detalhada desses papéis sociais, ver Colpron (2004:152-156).

12 Essa aproximação baseia-se nas estimativas de Morin (1998), que recenseou uma centena de onányabo. Ela permanece todavia incerta, já que nem todas as mulheres onányabo foram repertoriadas: algumas delas escaparam certamente da contagem, a maioria delas evitando tornar públicas suas atividades. Além disso, o número de onányabo varia de ano para ano (morte, novas iniciações, abandono da prática), o que torna a contagem bastante difícil. Algumas genealogias, que remontam a três gerações ascendentes de mulheres onányabo e meráyabo, permitem supor que, outrora, as mulheres xamãs tenham sido mais numerosas e poderosas. A antigüidade do fenômeno é defendida em Colpron (2004).

${ }^{13}$ As onányabo são designadas aqui por seus verdadeiros nomes, segundo sua própria vontade: desse modo, algumas buscam atrair uma clientela internacional; outras pretendem aumentar sua notoriedade junto aos seus. Refiro-me aos nomes em espanhol, pois são os mais utilizados pelos Shipibo-Conibo contemporâneos. Além disso, esses prenomes evitam a confusão, pois os nomes shipibo-conibo são, em sua maioria, termos múltiplos. 
${ }^{14} \mathrm{O}$ termo raté se refere a um grande susto que provoca a perda de um princípio vital.

${ }^{15} \mathrm{O}$ modo de residência shipibo-conibo é principalmente matri-uxorilocal, as mulheres vivendo, assim, cercadas de suas mães, irmãs, filhas; elas dispõem, desse modo, de uma rede de ajuda importante para o cuidado dos filhos.

${ }^{16}$ Exemplos citados ao longo do texto demonstram como certas partes animais (coração, cérebro, flegma etc., segundo o caso) são ditas ráo. O mesmo vale para ornamentos corporais rituais. Aliás, o termo equivalente em kaxinawa (outra sociedade da família lingüística pano), "dau", refere-se igualmente a remédios vegetais, animais, e ornamentos rituais (ver Kensinger 1998). Algumas vezes, objetos introduzidos há alguns séculos pelos europeus (livros, metal, ímãs e, mais recentemente, pilhas) são classificados como ráo, pois exibem um poder particular (a saber, o conhecimento, a resistência, a força de atração, a energia elétrica) e podem influenciar o comportamento humano.

${ }^{17}$ Como sustentam, por exemplo, McCallum (1996) para os Kaxinawa, Erikson (2003) para os Matis e Viveiros de Castro (1998) para a área amazônica em geral.

${ }^{18}$ Ervas da família Cyperaceae, regionalmente conhecidas pelo nome piripiri.

${ }^{19} \mathrm{O}$ sangue menstrual é considerado fortemente nefasto para a prática xamânica — seu mau odor afasta os aliados da floresta — e é freqüentemente invocado como razão da impossibilidade de um xamanismo feminino entre os Shipibo-Conibo (tanto por certos indígenas como por pesquisadores; cf. Roe 1988; Heise et alii 1999; Gebhart-Sayer 1986; Arévalo 1986). Ora, as mulheres onányabo recorrem a certos ráo para que seu sangue não comprometa suas aquisições. Tais práticas são explicitadas em Colpron (2004:325-333).

20 Taylor (1983) mostra, aliás, como tanto homens quanto mulheres achuar fazem uso de encantamentos amorosos cantados (anent).

${ }^{21}$ Esse conhecimento pode ser aprendido em livros especializados de magia que se vendem nas cidades.

${ }^{22}$ Os onányabo veiculam seus poderes soprando fumaça de tabaco no topo do crânio de seus aliados; todavia, usam também deste subterfúgio para aspirar as aquisições de seus rivais. 
${ }^{23}$ Um mito shipibo-conibo (ver Roe 1982) e um mito Sharanawa (P. Deleage, comunicação pessoal) associam explicitamente a minhoca ao falo.

${ }^{24}$ Um poder que lhe é imputado, o "canto do cachorro" (otxíti bewá), provoca o seguinte mal: os parceiros sexuais ficam presos por ocasião da cópula. A pessoa traída, chegando ao local do crime, pode, assim, confirmar seus temores.

25 Aliás, como já foi mencionado, uma onánya ciumenta do aprendizado de seu marido - que atraía tanto mulheres quanto caça - confiscou-lhe o conhecimento por meio de um "canto". Ela lhe confere, porém, um outro poder: "a veste invisível da sanguessuga" (réa tári), para que ele não se torne mau pescador. Os laços que os Shipibo-Conibo estabelecem entre caça e sedução permitem compreender como um tal uso do métxati ráo pode acarretar conseqüências sobre a sexualidade. Por exemplo, um caçador utiliza uma planta para atrair o peixe, mas infringe os tabus exigidos por este ráo. Em lugar de atrair o peixe, segue-se que uma de suas filhas manifesta uma sexualidade excessiva (tsínia): ela deve então ser tratada pelo onánya, que retira os efeitos do ráo.

${ }^{26}$ Em um mito shipibo-conibo, o martim-pescador se opõe ao urubu, pássaro sujo, preguiçoso e incompetente (yópa), antítese do bom caçador.

27 Os onányabo transmitem seus "poderes-cantados" sob a forma de desenhos invisíveis (ver Gebhart-Sayer 1986), mas também sob a forma de certos enfeites invisíveis, notadamente a coroa (máiti) e a banda peitoral (páoti) (ver Colpron 2004:301-314). A doença pode também tomar a forma de ornamentos corporais inusitados (ver o caso do boto mencionado anteriormente).

${ }^{28} \mathrm{O}$ dardo patogênico é extraído por intermédio de uma série de sucções sobre a parte corporal afetada, seja durante o dia — fumando-se grandes quantidades de tabaco - seja durante rituais noturnos.

${ }^{29}$ Uma tal resposta foi possivelmente induzida pela expressão empregada em minha pergunta, jawéki yóina, que designa sobretudo animais comestíveis.

${ }^{30}$ Devido ao sistema de residência matri-uxorilocal, as mulheres shipiboconibo vivem a maior parte do tempo cercadas de um grupo solidário de parentes; antigamente, o ritual mais importante tratava da puberdade feminina; hoje em dia, são famosas pela elaboração de um artesanato muito belo, que lhes confere independência econômica e grande mobilidade espacial. 


\section{Referências bibliográficas}

ALÈS, Catherine. 1998. "Pourquoi les Yanomamï ont-ils des filles?". In: M. Godelier e M. Panoff (éds.), La production du corps. Approches anthropologiques et historiques. Amsterdã: Édition des Archives Contemporaines.

ARÉVALO, Guillermo. 1986. "El ayahuasca y el curandero shipiboconibo del Ucayali". América Indigena 46(1):147-161.

ATKISON, Jane M. e Michelle ROSALDO. 1975. "Men the hunter and woman. Metaphors for the sexes in ilongot magical spells". In: R. Willis (éd.), The interpretation of symbolism. Nova Iorque: Halsted Press Book.

BACIGALUPO, Ana Mariella. 1998.

"Les chamanes mapuche et l'expérience religieuse masculine et féminine". Médiations chamaniques. Sexe et genre. Anthropologie et Sociétés, 22(2):123-143.

BARRAU, Jacques. 1990. "L'homme et le végétal". In: J. Poirier (éd.), Histoire des mœurs I: 1279-1306. Encyclopédie de la Pléiade. Paris: Gallimard.

BELLIER, Isabelle. 1991. El temblor y la luna: ensayo sobre las relaciones entre las mujeres y los hombres mai- huna. Lima: Institut Français d'Études Andines.

. 1993. "Réflexions sur la question du genre dans les sociétés amazoniennes". L'Homme, 126-128: 517-526.
CARDENAS, Clara. 1989. Los unaya y su mundo. Aproximacion al sistema medico de los shipibo-conibo del rio Ucayali. Lima: Instituto Indigenista Peruano/ CAAAP.

CAUQUELIN, Josiane. 2000. "Passage d'une société chamaniste à une société à chamanes. L'exemple des puyuma de Taiwan". In: D. Aigle et alii (éds.), La politique des esprits. Chamanisme et religions universalistes. Recherches thématiques 7. Nanterre: Société d'Ethnologie. pp. 35-50.

CHAUMEIL, Jean-Pierre. 1993. "L'autre sauvage. Chamanisme et altérité". In: C. Descamps (éd.), Amériques latines: une altérité. Paris: Éditions du Centre Pompidou. pp. 69-89.

__. 2000. Voir, savoir, pouvoir. Le chamanisme chez les yagua de l'Amazonie péruvienne. Genève: Georg. Collection Ethnos.

COLPRON, Anne-Marie. 2004. Dichotomies sexuelles dans l'étude du chamanisme: le contre-exemple des femmes chamanes shipiboconibo. Thèse de doctorat, Université de Montréal.

DESCOLA, Philippe. 1986. La nature domestique: symbolisme et praxis dans l'écologie des Ashuar. Paris: Édition de la Maison des Sciences de l'Homme.

. 1992. "Societies of nature and the 
nature of society". In: A. Kuper (éd.), Conceptualizing society. Londres: Routledge. pp. 107-126. . 1996. "Les cosmologies des indiens d'Amazonie". La Recher che, 292:62-67.

DESCOLA, Philippe e J-L. LORY. 1982. "Les guerriers de l'invisible. Sociologie comparative de l'agression chamanique en Hau te-Amazonie (Achuar) et en Papouasie Nouvelle-Guinée (Baru-ya)". L'Ethnographie, LXXVII (87-88):85-111.

ERIKSON, Philippe. 1996. La griffe des aïeux. Marquage du corps et démarquages ethniques chez les matis d'Amazonie. Paris, Louvain: Peeters / SELAF.

. 2003. "Comme à toi jadis on l'a fait, fais-le moi à présent...Cycle de vie et ornementation corporelle chez les Matis". L'Homme, 167-168:129-152.

FOLLER, Maj-Lis. 1990. Environmental changes and human health. A study of the shipibo-conibo in eastern Peru. Göteborg: Humanekologiska Skrifter 8.

GEBHART-SAYER, Angelica. 1985. "The geometric designs of the shipibo-conibo in ritual context". Journal of Latin American Lore, II(2):143-175.

. 1986. “Una terapia estetica. Los diseños visionarios del ayahuasca entre los shipibo-conibo". América Indigena, 46(1):189-218.

GOW, Peter. 1989. "The perverse child: desire in a native amazonian subsistence economy". Man, 24(4): 567-582.
HAMAYON, Roberte. 1982. "Des chamanes au chamanisme". L'Ethnographie, LXXVIII(87-88):13-48. . 1994. "Shamanism in Siberia: from partnership in supernature to counter-power in society". In: N. Thomas e C. Humphrey (éds.), Shamanism, history and the state. Ann Arbor: The University of Michigan Press. pp.76-89.

HEISE, Maria et alii. 1999. Relaciones de género en la Amazonia peruana. Lima: CAAAP.

HÉRITIER, Françoise. 1996. Masculinféminin. Paris: Odile Jacob.

HUGH-JONES, Christine. 1979. From the milk river: spatial and temporal processes in northwest Amazonia. Cambridge: Cambridge University Press.

HUGH-JONES, Stephen. 2001. "The gender of some amazonian gifts: an experiment with an experiment". In: T. Gregor e D. Tuzin (éds.), Gender in Amazonia and Melanesia: an exploration of the comparative method. Berkeley: University of California Press. pp.245-278.

HVIDING, Edvard. 1996. "Nature, culture, magic, science. On meta-language for comparison in cultural ecology". In: P. Descola e G. Palsson (éds.), Nature and society. Anthropological perspectives. London: Routledge. pp.165-184.

ILLIUS, Bruno. 1982. "Some observations on Shipibo-Conibo shamanism". 44th ICA, Manchester. Ms.

JACKSON, Jean. 1992. "The meaning and message of symbolic sexual 
violence in Tukanoan ritual". Anthropological Quarterly, 65(1): 1-18. JORDANOVA, Ludmilla. 1980. "Natural facts: a historical perspective on science and sexuality". In: C. P. McCormack (éd.), Nature, culture and gender. Cambridge: Cambridge University Press. pp.42-69.

KENSINGER，Kenneth. 1998. "Los cashinahua". In: F. Santos Granero e F. Barclay (éds.), Guia etnografica de la alta Amazonia vol. IV. Quito: Abya Yala. pp. 2-124.

KIRSCH, Chantal. 1977. "Forces productives, rapports de production et origine des inégalités entre hommes et femmes". Anthropologie et Sociétés,1(3):15-41. Le rapport hommes-femmes.

LEACOCK, Eleanor. 1980. “Montagnais women and the jesuit program for colonization". In: $\mathrm{M}$. Etienne e E. Leacock (éds.), Women and colonization. Anthropological perspectives. New York: Praeger. pp. 25-42.

LORIOT, James et alii. 1993. Diccionario shipibo-castellano. $\mathrm{Pu}-$ callpa: SIL. Serie Linguistica Peruana 31.

LORRAIN, Claire. 2000. "Cosmic reproduction, economics and politics among the Kulina of southwest Amazonia". Journal of the Royal Anthropological Institute, 6: 293-310. 2001. "The hierarchy bias and the equality bias: epistemological considerations on the analysis of gender". In: L. Rival e N. Whitehead (éds.), Beyond the visible and the material: the amerindianization of society in the work of Peter Rivière. Oxford: Oxford University Press.

McCALLUM, Cecilia. 1996. "The body that knows: from cashinahua epistemology to a medical anthropology of Lowland South America". Medical Anthropology Quartely, 10(3):347-372.

MEILLASSOUX, Claude. 1975. Femmes, greniers et capitaux. Paris: F. Maspero.

MENGET, Patrick. 1984. "Delights and danger. Notes on sexuality in the upper Xingu" . In: K.M.Kensinger (éd.), Sexual ideologies in Lowland South America. Working Papers on South American Indians 5. Vermont: Bennington College. pp. 4-11.

MÉTRAUX, Alfred. 1967. "Le chaman dans les civilisations indigènes des Guyanes et de l'Amazonie". In: ___. Religions et magies indiennes d'Amérique du Sud. Paris: Gallimard. pp. 81-101.

MORIN, Françoise. 1998. "Los ShipiboConibo" .In: F. Santos Granero e F. Barclay (éds.), Guia Etnografica de la Alta Amazonia vol. IV. Quito: Abya Yala. pp. 275-448.

MURPHY, Yolanda e Robert. 1974. Women of the forest. New York and London: Columbia University Press.

ORTNER, Sherry. 1974. "Is female to male as nature is to culture?". In: M Rosaldo e L. Lamphere (éds.), Woman, culture and society. California: Stanford University Press. pp. 67-87.

OVERING, Joanna. 1986. "Men control women? The cath 22 in the analysis 
of gender". International Journal of Moral and Social Studies, 1(2):135-156.

PERRIN, Michel. 1995. Le chamanisme. Que sais-je? Paris: Presse Universitaire de France.

. 2001. Les praticiens du rêve. Paris: Quadrige/ PUF.

REICHEL DOLMATOF, Elizabeth. 1999. "Cosmology, worldview and gender-based knowledge systems among the Tanimuka and Yukuna (Northwest Amazon)". Worldviews. Environment, Culture, Religion, 3(3):213-242.

ROE, Peter. 1982. The cosmic zygote. New Jersey: Rutgers University Press. . 1988. "The Josho Nahuanbo are all wet and udercook: Shipibo views of the witheman and the Incas in myth, legend, and history". In: J.D. Hill (éd.), Rethinking history and myth. Indigenous South American perspectives on the past. Chicago: University of Illinois Press. pp. 106135.

ROSALDO, Michelle. 1974. "Woman, culture and society: a theoritical overview". In: M. Rosaldo e L. Lamphere (éds.), Woman, culture and society. California: Stanford University Press. pp.17-42.

STRATHERN, Marilyn. 1988. The gender of the gift: Problems with women and problems with society in Melanesia. Berkeley: University of California Press.

TAYLOR, Anne-Christine. 1979. "Some aspects of the gender relation and its transformation among the ecuadorian Achuar". Communication $\mathrm{au}$ 43e Congrès International des Américanistes. Vancouver. 1983. "Jivaroan magical songs. Achuar anent of connubial love." Amerindia, 8:87-127.

1998. "Corps immortels, devoir d'oubli: formes humaines et trajectoires de vie chez les Achuar". In: M. Godelier e M. Panoff (éds.), La production du corps. Approches anthropologiques et historiques. Amsterdam: Édition de Archives Contemporaines.

TOURNON, Jacques. 1991a. "Medicina y visiones: canto de un curandero shipibo-conibo, texto y contexto". Amerindia, 16:179-209.

. 1991b. "La clasificación de las plantas entre los shipibo-conibo". Anthropologica, 9:119-151.

VIVEIROS de CASTRO, Eduardo. 1998. "Cosmological deixis and amerindian perspectivism". Journal of the Royal Anthropological Institute, 4(3):469-488.

YANAGISAKO, Sylvia e COLLIER, Jane. 1987. "Introduction" e "Toward a unified analysis of gender and kinship". In: . (éds.), Gender and kinship. Essays toward a unified analysis. California: Standford University Press. pp.1-50.

. 1989. "Theory in anthropology since feminist practice". Critique of Anthropology, 9(2):27-37. 


\section{Resumo}

A literatura etnológica sobre os ShipiboConibo da Amazônia ocidental atribui o papel prestigioso de xamã apenas aos homens. A pesquisa etnográfica nessa sociedade permitiu descobrir, porém, uma dúzia de mulheres xamãs que exercem atividades comparáveis a de seus confrades. Essas mulheres intervêm em domínios correntemente considerados masculinos na área amazônica: o controle da sexualidade, a caça e o xamanismo ofensivo/defensivo. Apresentando brevemente seus poderes xamânicos, este artigo procura nuançar as categorias sexuais típicas, próprias do estudo do xamanismo amazônico, visando demonstrar como as relações de gênero não são aqui necessariamente concebidas de maneira dicotômica e como a idéia de um xamanismo por essência masculino ocultou a existência de mulheres xamãs entre os Shipibo-Conibo.

Palavras-chave Amazônia, Gênero, Xamanismo, Shipibo-Conibo

\section{Abstract}

The ethnographic literature on the Shipibo-Conibo of Western Amazonia attributes the prestigious role of shaman to men only. However, my recent ethnographic research into this society has revealed at least a dozen female shamans who perform activities comparable to those of their male colleagues. These women intervene in what are typically considered to be male domains in Amazonia: the control of sexuality, hunting and offensive/defensive shamanism. Starting with a brief overview of their shamanic powers, this article looks to develop a more nuanced analysis of the sexual categories typical to the study of Amazonian shamanism, demonstrating how gender relations are not necessarily conceived here in a dichotomous fashion and how the idea of an essentially male shamanism has obscured the existence of female shamans among the Shipibo-Conibo.

Key words Amazonia, Gender, Shamanism, Shipibo-Conibo 